\title{
THE DEVELOPMENT OF REGULATION OF THE FAMILY AND MARRIAGE INSTITUTIONS IN RUSSIA IN THE CONTEXT OF THE DECISIONS OF THE EUROPEAN COURT OF HUMAN RIGHTS
}

\author{
Evgeny A. Mamay \\ Nizhny Novgorod Academy of the Ministry of Internal Affairs of Russia, Nizhny Novgorod, Russian Federation
}

Julia A. Ermakova

Nizhny Novgorod Academy of the Ministry of Internal Affairs of Russia, Nizhny Novgorod, Russian Federation

Introduction: the institution of marriage is the pillar of every society and state and forms their material, spiritual, psychological and even ideological basis. The state is inextricably linked with the family and marriage. Changing each of the elements of this interaction leads to the radical changes in the entire system, so the state must regulate these social institutions in a certain way. Modern Russia strives to achieve a reasonable balance of human rights and freedoms, develop a democratic society and work closely with the international community while preserving the established moral foundations and traditional values related to the institution of the family and marriage. The purpose of the publication is to determine the current state and prospective vectors of development of the state policy in relation to the institution of marriage. The research methodology is based on the use of the logical, dialectical techniques and methods of scientific knowledge, the comparative legal and legal-technical analysis of the texts of laws and other documents. Results: the paper analyzes the scientific literature, the Russian and foreign legislation, the international legal acts and decisions of the European Court of Human Rights in order to determine the efficiency of the state policy in this area, establish the criteria for achieving a sufficient balance between the non-interference of the state in the gender issues and maintaining the institution of traditional marriage in Russia. The conducted research of the issue suggests that in general, the legislation of the Russian Federation concerning the family and marriage relations is quite stable, but in

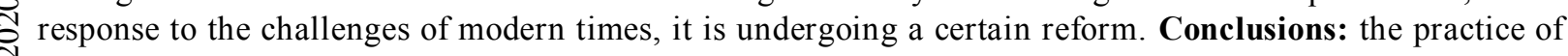
implementing the European Convention on Human Rights requires that the Russian legislation be seriously reformed in terms of regulating the gender issues and marital and family relations. In recent years, the Russian Federation has repeatedly lost cases in the European Court of Human Rights (ECHR), without being able to defend the fairness of its position. According to the authors of the publication, the solution to this problem is possible by reviewing certain international obligations of Russia in the context of their interpretation of the ECHR, as well as forming a consolidated position in Russian society regarding the institution of traditional marriage and the gender relations. These changes should be reflected in both the domestic legislation and the legalized law enforcement practices. The authors consider the achieved level of tolerance of Russian law regarding the institutions of the family and marriage to be extremely sufficient for the preservation and sustainable development of Russian society.

Key words: family, traditional marriage, same-sex union, the European Court of Human Rights, gender, LGBT. 
Citation. Mamay E.A., Ermakova Ju.A. The Development of Regulation of the Family and Marriage Institutions in Russia in the Context of the Decisions of the European Court of Human Rights. Legal Concept, 2020, vol. 19, no. 2, pp. 144-153. (in Russian). DOI: https://doi.org/10.15688/lc.jvolsu.2020.2.21

УДК 347.6

Дата поступления статьи: 03.03.2020

ББК 67.404 Дата принятия статьи: 03.04.2020

\title{
РАЗВИТИЕ РЕГУЛИРОВАНИЯ ИНСТИТУТОВ СЕМЬИ И БРАКА В РОССИИ В КОНТЕКСТЕ РЕШЕНИЙ ЕВРОПЕЙСКОГО СУДА ПО ПРАВАМ ЧЕЛОВЕКА
}

\author{
Евгений Алексеевич Мамай \\ Нижегородская академия МВД России, г. Нижний Новгород, Российская Федерация \\ Юлия Александровна Ермакова \\ Нижегородская академия МВД России, г. Нижний Новгород, Российская Федерация
}

Введение: институт брака является фундаментом каждого общества и государства и составляет их материальную, духовную, психологическую и даже идеологическую основу. Государство неразрывно связано с семьей и браком, изменение каждого из элементов указанного взаимодействия ведет к кардинальным изменениям всей системы, поэтому государство должно определенным образом регулировать указанные социальные институты. Современная Россия стремится к достижению разумного баланса прав и свобод человека, развитию демократического общества и тесному взаимодействию с международным сообществом при сохранении сложившихся морально-нравственных устоев и традиционных ценностей, относящихся к институту брака и семьи. Целью публикации является определение текущего состояния и перспективных векторов развития государственной политики в отношении института брака. Методология исследования базируется на применении логического, диалектического приемов и способов научного познания, сравнительно-правового и юридико-технического анализа текстов законов и иных документов. Результаты: в статье проводится анализ научной литературы, российского и зарубежного законодательства, международных правовых актов и решений Европейского суда по правам человека на предмет определения эффективности государственной политики в рассматриваемой сфере, установления критериев достижения достаточного баланса между невмешательством государства в гендерные вопросы и поддержанием института традиционного брака в России. Проведенное исследование вопроса позволяет говорить о том, что в целом законодательство Российской Федерации, касающееся брачно-семейных отношений, является достаточно стабильным, однако в ответ на вызовы современности оно подвергается определенному реформированию. Выводы: практика реализации Европейской конвенции по правам человека требует, чтобы российское законодательство было серьезно реформировано в части регулирования гендерных вопросов и брачно-семейных отношений. За последние годы неоднократно Российская Федерация проигрывала дела в Европейском суде по правам человека (ЕСПЧ), не имея возможности отстоять справедливость своей позиции. По мнению авторов публикации, решение указанной проблемы возможно путем пересмотра отдельных международных обязательств России в контексте их толкования ЕСПЧ, а также формирования консолидированной позиции в российском обществе относительно института традиционного брака и гендерных взаимоотношений. Данные изменения должны найти свое отражение как во внутреннем законодательстве, так и легализованной практике правоприменения. Достигнутый уровень толерантности российского права относительно институтов семьи и брака авторы считают предельно достаточным для сохранения и устойчивого развития российского общества.

Ключевые слова: семья, традиционный брак, однополый союз, Европейский суд по правам человека, гендер, ЛГБТ.

Цитирование. Мамай Е. А., Ермакова Ю. А. Развитие регулирования институтов семьи и брака в России в контексте решений Европейского суда по правам человека // Legal Concept = Правовая парадигма. 2020. - T. 19, № 2. -C. 144-153. -DOI: https://doi.org/10.15688/lc.jvolsu.2020.2.21 


\section{Введение}

Каждое общество и государство основано на социальных институтах, без которых их невозможно представить. В течение своей жизни человек проходит через многие из них, однако одним из самых первых и важных является семья. В традиционном понимании семья - это основанное на браке или родстве объединение лиц, связанных между собой взаимными личными и имущественными правами и обязанностями, взаимной моральной и материальной общностью и поддержкой, рождением и воспитанием потомства, ведением общего хозяйства [4, с. 46-48]. Институт брака неотделим от института семьи, вместе с тем, они имеют различную природу и характер взаимоотношений. Брачные отношения имеют многовековую историю и являются неотъемлемой частью любого общества, они образуют определенную материальную, духовную, психологическую и даже идеологическую основу каждого государства.

Брак - один из древнейших социальных институтов. О семье и браке - причем с точки зрения именно их социальных функций немало размышляли классики античной философии. Древнегреческий философ Платон в «Законах» и «Государстве» подробно раскрывает формы создания брака, необходимого для государства. Он считал, что дело мужчины осмысление и построение мира. Поскольку к созданию семьи и брака мужчины не имеют предрасположенности, то к формированию брачно-семейных отношений с женщиной их должен приучать обычай, поскольку «сами они вполне довольствуются холостою жизнью друг с другом» [6, с. 40].

В эпоху средневековья развитие взглядов на брачно-семейные отношения происходило под эгидой христианской церкви. Аврелий Августин - один из самых образованных людей IV-V вв., обосновавший в своем философском учении о браке его эстетическую ценность и смысл как непреходящего элемента европейского сознания. Августин посвятил ряд работ вопросу брака и его роли в обществе («О супружеском благе», «О супружестве и похоти», «О свободном решении», «О святом девстве» и др.). Целью брака, по его мнению, является размножение, а смыслом - красота отноше- ний мужчины и женщины. Данная идея основана на Библии, поскольку еще до грехопадения Бог сказал Адаму и Еве: «Плодитесь и размножайтесь» (Быт. 1:28). В работе «О супружеском благе» автор говорит о браке как о священном таинстве, один из смыслов брака, по убеждению Августина, заключается не в половой жизни, а в красоте человеческих отношений между мужчиной и женщиной: «Иосиф и Мария, по мнению Августина, были супругами, хотя и не имели половых отношений» [9, с. 225]. Данноеучение, основанное на христианском восприятии брачных отношений, долгое время было надежным ориентиром общественной жизни многих христианских стран.

В XVIII - начале XIX в. брак все больше начинает осознаваться как личностный союз. Он постепенно выходит из-под церковной монополии, все большую роль в браке приобретают договорные отношения. Кант считал, что характерной правовой чертой брака является существование в нем двух частей одинаковой значимости. Во-первых, фактическое сожительство не является браком, поскольку оно не закреплено законом. Но, с другой стороны, и брачный договор сам по себе ничего не стоит, ибо он может быть фиктивным. Кроме того, Кант подчеркивает моральный аспект брака. Без согласия сторон и взаимной доброй воли брак существовать не может. Это согласие должно быть полным и добровольным. Вступление в брак должно быть осознанным поступком как со стороны мужчины, так и со стороны женщины.

В XX в. сформировались различные взгляды на тему социальной значимости и исторической изменчивости семьи и брака. Так, один из представителей социологической науки новейшего времени Энтони Гидденс уже представляет брак «как получивший признание и одобрение со стороны общества сексуальный союз двух взросльх лии (выделено нами. - E. M., Ю. E.)» [2, с. 301].

Отметим, что брак играет важную морально-нравственную и социальную роль не только для общества, но и для государства. Именно брачно-семейные отношения представляют собой минимодель государства, его устройство, идеологию и т. д. Государство неразрывно связано с семьей и браком, изменения с одной стороны ведут к кардинальным 
изменениям с другой стороны, поэтому государство пытается определенным образом регулировать данный социальный институт.

\section{Толкование и правовая регламентация семейных и брачных отношений в странах современного мира}

Законодательство Российской Федерации не дает точного определения института «брака», однако существует множество доктринальных подходов к его определению. А.И. Загоровский полагал, что «брак - это семейный союз мужчины и женщины, порождающий их права и обязанности по отношению к друг другу и к детям» [3, с. 25]. Несколько иначе определял это понятие Г.Ф. Шершеневич, по его мнению, «брак - это союз мужчины и женщины с целью сожительства, основанный на взаимном соглашении и заключенный в установленной форме» [8, с. 674-675]. А.Х. Харчев дает следующее определение: «Брак есть исторически изменяющаяся социальная форма отношений между мужчиной и женщиной, посредством которого общество упорядочивает и санкционирует их половую жизнь и устанавливает их супружеские и родительские права и обязанности» [7, с. 66].

На протяжении всей истории человечества брачные отношения постоянно развивались и эволюционировали, однако в любом своем понимании данный институт наделяется следующими признаками. Во-первых, брак - это отношения, то есть связь между людьми, складывающаяся в процессе их совместной материальной и духовной деятельности. Во-вторых, выделяют формальный признак, который выражается в соблюдении установленной формы - регистрации заключения брака. В-третьих, определенная совокупность прав и обязанностей, которые возникают в связи с заключением брака как между супругами по отношению друг к другу, так и по отношению к детям. Во всех же традиционных подходах неизменным является определение брака в качестве союза мужчины и женщины.

Между тем в современном мире произошли серьезные изменения, которые затронули и институт брака. На сегодняшний день многие страны мира официально признали и разрешили существование однополых союзов, которые отстаивают права на уважение своего выбора и требуют получения полного юридического равенства в официальном регулировании своих отношений. По данному вопросу государства мира и, соответственно, общества разделились на три лагеря.

Первая группа стран предоставляют однополым парам права регистрировать свои союзы как брак, приобретать все права и обязанности, которые имеют традиционные брачные союзы, в том числе на наследование имущества, усыновление или удочерение и т. д. Представителями данного лагеря являются Швеция, Голландия, Великобритания, Исландия и некоторые другие государства.

Вторую группу формируют страны, которые не регистрируют однополые браки, но разрешают заключать так называемое «гражданское партнерство», то есть легализованную форму однополого сожительства, по своим правовым последствиям во многом подобную браку. Одной из таких стран является Финляндия, законодательство которой не приравнивает однополые браки к традиционным, однако официально рассматривает данный вид отношений как «гражданский союз». Пункт 1 ст. 8 Закона о гражданском союзе Финляндии гласит: «Регистрация гражданского союза имеет такие же правовые последствия, как и заключение брака, если не предусмотрено иное» [15].

Последнюю группу составляют государства, которые не только не регистрируют, но и не принимают однополые союзы либо не регулируют эти отношения вообще. Например, Семейный кодекс РФ четко устанавливает, что для заключения брака необходимо «взаимное добровольное согласие мужчины и женщины» (ст. 12). Институт однополого союза («гражданского партнерства») в России не признается и не может быть зарегистрирован в качестве брака. Неизменность данной нормы базируется на стремлении государства сохранить традиционный институт брака, который является идеологической, морально-нравственной и духовной основой российского общества.

Несмотря на давнее историческое присутствие однополых отношений во многих обществах мира, в собственно юридическом 


\section{МЕЖДУНАРОДНОЕ ПРАВО И СРАВНИТЕЛЬНОЕ ПРАВОВЕДЕНИЕ}

смысле проблема правовой регламентации и судебной оценки таких изменений остро встала только на рубеже XX-XXI веков. Только в практике Европейского суда по правам человека (ЕСПЧ) на данный момент можно найти несколько десятков дел, связанных с рассмотрением вопросов об отношениях между полами в брачных, семейных союзах, гомосексуальных половых связях, профессиональных отношениях и т. п. Наиболее известны в этом отношении дела Кэрнер против Австрии (Karner v. Austria), Л. и Ви. Против Австрии (L. and V. v. Austria), Смит и Грейди против Соединенного Королевства (Smith and Grady v. the United Kingdom), Тлимменос против Греции (Thlimmenos v. Greece).

Общим вектором развития судебной практики ЕСПЧ является требование признания юридического равенства сексуальных меньшинств в разного рода общественных отношениях, однако наиболее гипертрофированный характер таковое обретает в сфере именно брачно-семейных отношений. Характерным в этом отношении является дело 2014 г. «Хэмэлайнен против Финляндии» (Hamalainen v. Finland) [10], впервые рассмотренное финляндскими судами в 2008-2009 годах. В указанном деле рассматривался спор относительно правомерности действий органов власти Финляндии в отношении гражданки Хели Хэмэлайнен, заявительницы, чей биологический пол по рождению был мужским. В 1996 г. она, на тот момент еще будучи мужчиной, вступила в супружеские отношения с женщиной, а в 2002 г. у них родился ребенок. В 2006 г. Хэмэлайнен был официально признан лицом, страдающим транссексуализмом. В 2009 г. ему была сделана операция по смене пола (с мужского на женский), после чего он изменил свое имя, поменял паспорт и водительское удостоверение, но не смог сменить Henkilötunnus (известный также как KELA ID или HETU) - личный идентификационный код, выдаваемый финскими властями каждому жителю Финляндии, в котором указывается пол гражданина.

В указанном деле аргументация финских властей базировалась на том, что законодательство Финляндии не разрешает однополые браки, а рассматриваемый вид отношений официально определяет как «гражданский союз». В то же время Закон о гражданском союзе Финляндии предусматривает необходимость получения согласия жены и развод для смены личного идентификационного номера. Жена Хэмэлайнен не давала согласие на развод, ссылаясь на противоречие такого решения их религиозным взглядам. Аргументация истца строилась на том, что до операции они уже состояли в браке и в Законе о трансгендерах Финляндии (о подтверждении пола) (законопроект правительства № HE56/2001 vp) указывается, interalia, что установленное отцовство не может быть отменено только на основании того, что мужчина впоследствии стал женщиной.

Дело Хэмэлайнен в конечном итоге дошло до Большой Палаты Европейского суда по правам человека и стало в определенном смысле показательным. В 2012 г. данное дело выиграла Финляндия, но в 2014 г. Большая Палата ЕСПЧ подтвердила неправомерность вмешательства финских властей в права заявительницы, предусмотренные ст. 8 Конвенции. В своем решении суд указал: «Мы утверждаем, что правомерной цели защиты традиционной семьи не будет нанесен ущерб, если лицам, находящимся в ситуации, аналогичной ситуации заявительницы и ее супруги, будет разрешено оставаться в браке после признания приобретенного пола одной из сторон брака». Очевидно, что своим решением ЕСПЧ открывает пути не только для фактического, но и юридического приравнивания традиционных семейных отношений и однополых партнерств.

\section{Влияние решений Европейского суда по правам человека на изменение регулирования гендерных вопросов в Российской Федерации}

В России значительная часть населения неоднозначно относится к представителям нетрадиционной сексуальной ориентации, а также к пропаганде соответствующего образа жизни, особенно в среде несовершеннолетних. По этой причине ст. 6.21 Кодекса об административных правонарушениях Российской Федерации была введена ответственность за пропаганду нетрадиционных сексуальных отношений среди несовершеннолетних, предус- 
матривающая возможность применения к виновным достаточно жестких мер ответственности. Отметим, что западное международное сообщество не одобряет данные действия официальных властей России, в силу чего в Европейском суде по правам человека уже неоднократно инициировались дела о нарушении ст. 10 «Свобода выражения мнения» и ст. 11 «Свобода собраний и объединений» Европейской конвенции по правам человека (далее - Конвенция), по которым Российская Федерация из раза в раз оказывается неспособной отстоять свою правоту.

Одним из показательных решений ЕСПЧ в отношении России по данному вопросу является решение по делу 2019 г. «Жданов и другие против России» (Zhdanov and others v. Russia) [11]. Обращение в суд заявителей было мотивировано официальным отказом российских властей зарегистрировать ассоциации, созданные для поощрения и защиты прав представителей ЛГБТ в России, включая право на однополые браки. Европейский суд по правам человека посчитал, что в данном случае было нарушено право заявителей на свободу ассоциаций, поскольку цели их создания не противоречили законодательству Российской Федерации, в частности, российской Конституции, которая запрещает создание лишь общественных объединений, «цели или действия которых направлены на насильственное изменение основ конституционного строя и нарушение целостности Российской Федерации, подрыв безопасности государства, создание вооруженных формирований, разжигание социальной, расовой, национальной и религиозной розни». В аргументации своих действий национальные российские власти высказали мнение об экстремистском характере ассоциаций-заявителей, поскольку их создание угрожает суверенитету, безопасности и территориальной целостности России, а деятельность может привести к сокращению населения страны. В итоге ЕСПЧ принял сторону заявителей и подтвердил нарушение ч. 1 ст. 6 Конвенции в заявлении № 58282/12, ст. 14 Конвенции во взаимосвязи со ст. 11 во всех жалобах.

Еще одним делом, рассматриваемым в ЕСПЧ и касающимся пропаганды нетрадиционной сексуальной ориентации, является Дело
Баева и других против России (Case of Bayev and others v. Russia) [12]. В данном деле Баев, Киселев и Алексеев, являясь защитниками прав и интересов представителей ЛГБТ сообщества, занимались пропагандой нетрадиционной сексуальной ориентации и были оштрафованы в административном порядке за организацию протеста против законов, которые были приняты сначала на региональном, а затем на федеральном уровне и запрещали пропаганду гомосексуализма среди несовершеннолетних. Представитель России в ЕСПЧ отстаивал позицию о необходимости законодательного запрета на подобную деятельность в целях защиты нравственности и семейных ценностей, охраны здоровья и защиты прав других лиц. Согласно же решению ЕСПЧ, не было никаких оснований полагать, что признание социальной приемлемости гомосексуализма несовместимо с сохранением семейных ценностей в качестве основы общества, а ограничение потенциальной свободы выражения мнений по вопросам ЛГБТ будет способствовать снижению рисков для здоровья. В данном случае суд также постановил, что в деле имело место нарушение ст. 10 и 14 Конвенции.

Рассматривая решения ЕСПЧ относительно дел, касающихся прав и свобод сексуальных меньшинств, можно сделать вывод о том, что европейская судебная практика все чаще принимает сторону заявителей. Российская же Федерация, как и многие другие государства, в свою защиту использует доводы о необходимости сохранения устоев, нравственности, традиционных ценностей, включая институты брака и семьи, охраны здоровья и защиты прав других лиц. В то же время следует признать, что продемонстрированная в деле «Жданов и другие против России» аргументация об экстремистском характере подобной деятельности выглядит сильно натянутой, хотя она и нашла отражение в некоторых решениях и территориальных органов Минюста России, и судов, и экспертных заключениях научных и образовательных учреждений. Мы считаем, что в таком употреблении само понятие «экстремизм» и явления, трактуемые в подобном качестве, становятся чрезвычайно размытыми, что к тому же противоречит и официальному определению, зафиксированному в Федеральном законе от 
25 июля 2002 г. № 114-Ф3 «О противодействии экстремистской деятельности».

По нашему мнению, органам власти Российской Федерации следует сформировать общую официальную точку зрения со ссылкой как на внутреннее законодательство, так и сложившуюся практику правоприменения, а также нормы международного права. К примеру, нам видятся правомерными действия российских властей, поскольку в соответствии с п. 2 ст. 29 Всеобщей декларации прав человека, принятой Генеральной Ассамблеей $\mathrm{OOH}$ 10 декабря 1948 г., при осуществлении своих прав и свобод каждый человек должен подвергаться только таким ограничениям, какие установлены законом исключительно с целью обеспечения должного признания и уважения прав и свобод других и удовлетворения справедливых требований морали, общественного порядка и общего благосостояния (выделено нами. - Е. М., Ю. Е.) в демократическом обществе. Пункт 2 ст. 10 этой же Конвенции предусматривает возможность осуществления свободы на выражение мнения, сопряженное с определенными формальностями, условиями, ограничениями или санкциями, которые предусмотрены законом и необходимы не только в интересах национальной безопасности, территориальной целостности или общественного порядка, но и для охраны здоровья и нравственности.

ЕСПЧ же в своих решениях оперирует тем, что в Европе был достигнут четкий консенсус в отношении признания права отдельных лиц открыто признавать себя геями, лесбиянками или любыми другими сексуальными меньшинствами и защищать свои права и свободы. В подобном позиционировании нам видится опасность ущемления интересов большинства в угоду таким меньшинствам. Дело в том, что в зарубежной научной литературе достаточно давно обсуждается природа гомосексуальности. В ответе на данный вопрос многочисленные исследования показали, что гомосексуальность не относится к явлениям, биологически предопределяющимся какими-то генетическими особенностями человеческого организма. По мнению ученых, мужской и женский гомосексуализм, как и все сексуальности, являются социальной конст- рукцией [13], то есть лишь в единичных случаях подобные проявления сексуальной идентичности личности имеют биологическую предопределенность. Более того, еще в 2006 г. Линда Гарнетс и Энн Пеплау обнаружили, к примеру, что сексуальная ориентация женщин может меняться в течение жизни и «определяется такими социальными и культурными факторами, как образование, социальный статус и власть, экономические возможности и отношение к роли женщин» [14]. Исходя из сказанного, нам видится верным выбранный Российской Федерацией путь правового регулирования, строящийся на консервативном понимании прав человека, связанных с выбором гендерного статуса.

Не в последнюю очередь под влиянием решений ЕСПЧ, с 2017 г. в России официально разрешили проводить операции по смене пола при наличии на то медицинских показаний. В ст. 70 Федерального закона «Об актах гражданского состояния» российский законодатель предусмотрел возможность внесения исправлений или изменений в запись акта гражданского состояния при предоставлении справки о смене пола установленного образца. Проблема реализации данного права заключалась в том, что форма справки о смене пола была разработана только в 2017 г., в то время как норма федерального закона формально действовала с 2013 года. Думается, что данное законодательное решение является наиболее правильным с точки зрения нахождения баланса в социальном и биологическом проявлении рассматриваемого вопроса. Самым громким случаем, связанным с легализацией таких действий, стало заключение официального брака между трансгендерами в Казани в декабре 2019 года [1]. В приведенном случае новоиспеченная пара официально соответствовала всем установленным требованиям (бывшая женщина официально стала мужчиной, а бывший мужчина - женщиной), у органов ЗАГСа не было формальных оснований для отказа в удовлетворении соответствующих заявлений, поскольку на данный момент законодательство Российской Федерации признает не только юридическую возможность смены пола, но и открывает возможность для узаконения супружеских отношений между такими лицами. 


\section{Заключение}

Важно отметить, что в целом законодательство Российской Федерации, касающееся брачно-семейных отношений, является достаточно стабильным, однако и в ближайшее время в нем, по всей видимости, должны произойти некоторые изменения. В своем Послании Федеральному собранию 15 января 2020 г. президент В.В. Путин предложил внести поправки в Конституцию России, которые также затронут институт брака. В частности, предлагается дополнить ч. 1 ст. 72 п. «ж1»: «защита семьи, материнства, отцовства и детства; защита института брака как союза мужчины и женщины...». С одной стороны, подобные изменения во многом носят характер юридической формальности, так как и действующее законодательство Российской Федерации разрешает только разнополые браки, но с другой - меняется само восприятие данной нормы. Если предлагаемые изменения вступят в законную силу после проведения общероссийского референдума, то для последующего ее изменения потребуется более сложная процедура, чем та, которая предусмотрена для внесения изменений в федеральный закон.

В отстаивании своей позиции Российская Федерация ссылается на категоричное восприятие значительной частью населения однополых союзов и представителей нетрадиционной сексуальной ориентации, в то же время нельзя и отрицать, что за последние десятилетия наша страна пережила серьезные изменения как политического, так и идеологического характера. Если в СССР существовала установленная идеология, которая была ориентиром многим поколениям, то Россия сегодня не обладает данным духовно-нравственным ресурсом. Современное поколение не имеет четких установок и ориентиров относительно многих вопросов, в том числе и институтов брака и семьи, поэтому приходится констатировать все более толерантное отношение российского общества к представителям ЛГБТ. Несмотря на возможную тенденциозность и недостаточную прозрачность выборки, обращают на себя внимание результаты одного из последних социологических исследований, проведенных аналитическим центром Юрия Левады по данному вопросу. На вопрос о признании равноправия представителей нетрадиционной и традиционной сексуальной ориентации мнения респондентов разделились почти поровну - 47 \% выступили «за» и 43 \% «против». В то же время больше половины (56 \%) опрошенных заявляют о своем негативном отношении к ЛГБТ-сообществу, в то время как почти $40 \%$ россиян относятся к ним нейтрально [5]. Таким образом, несмотря на изменение отношения граждан России к сексуальным меньшинствам в положительную сторону, общество в нашей стране не способно до конца принять их. Согласно вышеприведенному опросу около $90 \%$ россиян не имеют знакомых людей гомосексуальной ориентации. Такой результат исследования может означать, что либо действительно незначительное количество подобных людей в нашем обществе, либо их боязнь раскрыть свою гомосексуальную ориентацию изза опасения общественного порицания, потери связей со знакомыми и друзьями (согласно опросу, 31 \% опрошенных полностью бы прекратили общаться со своими знакомыми, если бы узнали, что они нетрадиционной сексуальной ориентации).

Современная Россия стремится к достижению разумного баланса прав и свобод человека, развитию демократического общества и тесному взаимодействию с международным сообществом, однако по многим причинам не стремится полностью привести все свои общественные институты в соответствие с европейскими правовыми и социальными стандартами. В настоящее время наше общество претерпевает некоторые идеологические и морально-нравственные изменения, в том числе и в сфере брачно-семейных отношений. Несмотря на неоднократно проигранные в ЕСПЧ дела, касающиеся прав сексуальных меньшинств, Российская Федерация, являясь консервативным государством, бережет присущие ей традиционные ценности институтов семьи и брака. В период, когда нашей стране предстоит пережить серьезные изменения, гражданам России и ее властям важно достичь понимания взаимных интересов, избежать радикализации общества, воспитать у населения терпимость и привить уважение к выбору других граждан. 


\section{СПИСОК ЛИТЕРАТУРЫ}

1. В Казани ЗАГС зарегистрировал брак трансгендеров. - Электрон. текстовые дан. - Режим доступа: https://kazanfirst.ru/news/506511. - Загл. с экрана.

2. Гидденс, Э. Социология / Э. Гидденс. - М. : Эдиториал УРСС, 1999. - 703 с.

3. Загоровский, А. И. Курс семейного права / А. И. Загоровский. - Одесса : «Экономическая» типография, 1902. -460 с.

4. Матвеев, Г. К. Советское семейное право / Г. К. Матвеев. - М. : Юрид. лит., 1985. - 208 с.

5. Отношение к ЛГБТ-людям. - Электрон. текстовые дан. - Режим доступа: https://www. levada.ru/2019/05/23/otnoshenie-k-lgbt-lyudyam/. Загл. с экрана.

6. Платон. Пир: Беседа о любви / пер. с греч. И. Д. Городецкий. - М. : Дилетант, 1908. - 102 с.

7. Харчев, А. Г. Брак и семья в СССР / А. Г. Харчев. - М. : Мысль, 1979. - 367 с.

8. Шершеневич, Г. Ф. Учебник русского гражданского права / Г. Ф. Шершеневич. - М. : Типография товарищества И.Н. Кушнерев и К ${ }^{\circ}, 1912 .-951$ с.

9. Эриксен, Т. Б. Августин. Беспокойное сердце / Т. Б. Эриксен. - М. : Прогресс-Традиция, 2003. $-384 \mathrm{c}$.

10. Case of Hämäläinen v. Finland. - Electronic text data. - Mode of access: http://hudoc.echr.coe.int/ eng? $i=001-145768$. - Title from screen.

11. Case of Zhdanov and others v. Russia. Electronic text data. - Mode of access: http://hudoc. echr.coe.int/rus?i=001-194448. - Title from screen.

12. Case of Bayev and others v. Russia. - Electronic text data. - Mode of access: https://hudoc.echr.coe.int/ rus\# $\{\% 22$ tabview\%22:[\%22document $\% 22], \% 22$ itemid $\% 22:[\% 22001-174422 \% 22]\}$. - Title from screen.

13. Copland, S. Born this way? Society, sexuality and the search for the 'gay gene' / S. Copland. Electronic text data. - Mode of access: https://www. theguardian.com/science/blog/2015/jul/10/born-thisway-society-sexuality-gay-gene. - Title from screen.

14. Garnets, L. A New Paradigm for Women's Sexual Orientation / L. Garnets, L. Peplau // Women \& Therapy.-2002.-№ 24:1-2.-P. 111-121.-DOI: https:// doi.org/10.1300/J015v24n01_14.

15. Lag om registrerat partnerskap № 950, 09.11.2001. - Electronic text data. - Mode of access: https://www.finlex.fi/sv/laki/ajantasa/2001/20010950. Title from screen.

\section{REFERENCES}

1. V Kazani ZAGS zaregistriroval brak transgenderov [In Kazan, the Registry Office Registered a Transgender Marriage]. URL: https:// kazanfirst.ru/news/506511 (accessed 10 March 2020).

2. Giddens A. Sociologiya [Sociology]. Moscow, Editorial URSS Publ., 1999. 703 p.

3. Zagorovskii A.I. Kurs semeinogo prava [Family Law Course]. Odessa, «Ekonomicheskaya» tipografiya, $1902.460 \mathrm{p}$.

4. Matveev G.K. Sovetskoe semeinoe pravo [Soviet Family Law]. Moscow, Yurid. lit. Publ., 1985. 208 p.

5. Otnoshenie k LGBT-lyudyam [Attitude to LGBT People]. URL: https://www.levada.ru/2019/05/23/ otnoshenie-k-lgbt-lyudyam/ (accessed 10 March 2020).

6. Gorodetskii I.D., ed. Platon. Pir: Beseda o lyubvi [The Symposium: Erotic Dialogues]. Moscow, Diletant Publ., 1908. 102 p.

7. Kharchev A.G. Brak i semya v SSSR [Marriage and Family in the USSR]. Moscow, Mysl Publ., 1979. $367 \mathrm{p}$.

8. Shershenevich G.F. Uchebnik russkogo grazhdanskogo prava [Textbook of Russian Civil Law]. Moscow, Tipografiia tovarishchestva I.N. Kushnerev i K, $1912.951 \mathrm{c}$.

9. Eriksen T.B. Avgustin. Bespokoinoe serdtse [Augustine. Restless Heart]. Moscow, ProgressTraditsiia Publ., 2003. 384 p.

10. Case of Hämäläinen v. Finland. URL: http:// hudoc.echr.coe.int/eng?i=001-145768 (accessed 10 March 2020).

11. Case of Zhdanov and others v. Russia. URL: http://hudoc.echr.coe.int/rus?i=001-194448 (accessed 10 March 2020).

12. Case of Bayev and others v. Russia. URL: https://hudoc.echr.coe.int/eng\# $\{\% 22$ tabview $\%$ 22:[\%22document $\% 22.06 .2012], \% 22$ itemid $\%$ 22:[\%22001-174422\%22]\} (accessed 10 March 2020).

13. Copland S. Born this Way? Society, Sexuality and the Search for the 'Gay Gene'. URL: https://www. theguardian.com/science/blog/2015/jul/10/born-this-waysociety-sexuality-gay-gene (accessed 10 March 2020).

14. Garnets L., Peplau L. A New Paradigm for Women's Sexual Orientation. Women \& Therapy, 2002, no. 24:1-2, pp. 111-121. DOI: https://doi.org/10.1300/ J015v24n01_14.

15. Lag om Registrerat Partnerskap № 950, 09.11.2001. URL: https://www.finlex.fi/sv/laki/ ajantasa/2001/20010950 (accessed 10 March 2020). 


\section{Information About the Authors}

Evgeny A. Mamay, Candidate of Sciences (Jurisprudence), Associate Professor, Department of Constitutional and International Law, Nizhny Novgorod Academy of the Ministry of Internal Affairs of Russia, Ankudinovskoe Shosse, 3, 603144 Nizhny Novgorod, Russian Federation, formyjob2020@mail.ru, https://orcid.org/0000-0002-9386-2747

Julia A. Ermakova, Master Student, Department of Criminalistics, Nizhny Novgorod Academy of the Ministry of Internal Affairs of Russia, Ankudinovskoe Shosse, 3, 603144 Nizhny Novgorod, Russian Federation, ermakovayu1232000@gmail.com, https://orcid.org/0000-0002-0872-8974

\section{Информация об авторах}

Евгений Алексеевич Мамай, кандидат юридических наук, доцент кафедры конституционного и международного права, Нижегородская академия МВД России, Анкудиновское шоссе, 3, 603144 г. Нижний Новгород, Российская Федерация, formyjob2020@mail.ru, https://orcid.org/0000-0002-9386-2747

Юлия Александровна Ермакова, магистрант кафедры криминалистики, Нижегородская академия МВД России, Анкудиновское шоссе, 3, 603144 г. Нижний Новгород, Российская Федерация, ermakovayul232000@gmail.com, https://orcid.org/0000-0002-0872-8974 